Bond University

Research Repository

\title{
Consumer insights and the importance of competitiveness Factors for mature and developing destinations
}

Wilde, Simon J.; Cox, Carmen; Kelly, Stephen J.; Harrison, Jennifer L.

Published in:

International Journal of Hospitality and Tourism Administration

DOI:

10.1080/15256480.2016.1264902

Licence:

Other

Link to output in Bond University research repository.

Recommended citation(APA):

Wilde, S. J., Cox, C., Kelly, S. J., \& Harrison, J. L. (2017). Consumer insights and the importance of

competitiveness Factors for mature and developing destinations. International Journal of Hospitality and Tourism Administration, 18(2), 111-132. https://doi.org/10.1080/15256480.2016.1264902

\section{General rights}

Copyright and moral rights for the publications made accessible in the public portal are retained by the authors and/or other copyright owners and it is a condition of accessing publications that users recognise and abide by the legal requirements associated with these rights.

For more information, or if you believe that this document breaches copyright, please contact the Bond University research repository coordinator. 


\title{
Consumer Insights and the Importance of Competitiveness Factors for Mature and Developing Destinations
}

\begin{abstract}
This paper aims to understand the importance of various destination attributes to the competitiveness of tourism destinations from a consumer perspective, while at the same time contrasting these in a mature versus developing destination. A sample of Australian-based domestic tourists were surveyed to assess the relative importance of TDC attributes in the context of developing and mature destinations. This research firstly appears to verify that the importance of many TDC elements, highlighted by consumers, is not dissimilar from other stakeholderbased TDC studies. Furthermore, this research effort established that in terms of attribute performance, relative destination immaturity may well constrain a developing destination's ability to satisfy the needs of consumers.
\end{abstract}

Keywords: tourism destination competitiveness, attribute importance, consumer views, regional Australia, exploratory factor analysis. 


\section{INTRODUCTION}

Destination competitiveness has been claimed to be 'tourism's holy grail', however, research into this notion has only emerged since the 1990s (Ritchie \& Crouch, 2000). Tourism researchers have endeavoured to highlight how tourism destination competitiveness (TDC) is to be considered, conceptualised, and ultimately measured (Leung \& Baloglu, 2013; Prideaux, Berbigier \& Thompson, 2013; Crouch, 2007; Ritchie \& Crouch, 2003; Ritchie, Crouch \& Hudson 2001). As noted by Crouch (2007), one of the most pressing research needs is to better understand the relative importance of attributes of destination competitiveness. This focus would appear prudent and timely, given the necessity for destinations to formulate competitive strategies, based on finite resources. Through this context, many practical stakeholder-based TDC studies (see for example Omerzel, 2005; Enright \& Newton 2004, 2005; Hudson et al., 2004; Dwyer, Livaic \& Mellor, 2003) have been undertaken. However, these stakeholder-based TDC studies have also called for the need to incorporate consumer input and perceptions, into future TDC research undertakings. The inclusion of consumer views can be expected to provide a richer interpretation of the notion of tourism destination competitiveness. Therefore, in seeking to ascertain ratings of importance across a series of competiveness elements from actual consumers, it is the purpose of this paper to present empirical findings of importance based on the views of consumers. Further to this aim, the repercussion of a destination's stage of development on the performance of a destination, whilst postulated within the TDC literature, is not well supported empirically (Buhalis, 2000; Dwyer \& Kim, 2003). Integrating a destination's development cycle with the concept of destination competitiveness has the potential to assist destination marketing and management organisations to better devise appropriate management strategies for their destinations as they reach various stages of the life cycle. For example, given that infrastructure 
development of tourism destination areas has implications for the types of tourists that will be attracted (Ryan, 1991), it is critical, therefore, to understand both the stage and roots of tourism development when developing a competitive strategy for a destination (Buhalis, 2000). Assessing the performance of destinations at differing stages of development across a series of destination attributes from the consumers' perspective is a useful contribution toward the investigation of destination competitiveness. This, therefore, is a secondary aim of this paper.

\section{FRAMEWORKS AND ATTRIBUTES OF DESTINATION COMPETITIVENESS}

As can be observed from the TDC literature, a number of variables appear to be linked to the theory of destination competitiveness. Thus, frameworks and models investigating the competitiveness of tourism destinations must recognise a wide array of key success drivers and vital linkages involved in this complex construct. Within the tourism literature, an increasingly systematic research approach has been adopted towards the concept of TDC (Lee \& King, 2006). Porter's (1979) Framework for Industry Analysis was utilised by Ritchie \& Crouch (1993) as a foundation for researching destination competitiveness. Ritchie and Crouch (1993), via a series of industry stakeholder focus groups (and other discussion forums), developed the Calgary Model of Tourism Competitiveness. Ritchie and Crouch (1993) argued that the nature of economic competitiveness models, such as those advanced by Porter, appeared to be just as applicable at the destination level (Table 1). Industry stakeholders involved in the focus groups included 'experts' such as managers within some form of destination management organisation, such as national tourism administrations, or convention and visitor bureaus (and similar types of bodies), postgraduate tourism students, and tourism researchers. The model proposed by Ritchie and Crouch (1993), which was further refined by the authors (see Ritchie \& Crouch, 2003), pointed to 
the necessity to investigate and better understand the complex relationships and subsequent interplay among the various forces that can impact the competitiveness of a destination.

\section{INSERT}

Table 1. The Calgary Model of Competitiveness in Tourism Factors of Destination Competitiveness

Additional frameworks have also been developed, such as Heath (2003); Gooroochurn and Sugiyarto (2004), and Murphy, Pritchard and Smith (2000), whose simplified model (Figure 1) highlights that the ultimate outcome of destination competitiveness is the visitors' intention to return to a region. While these competitiveness frameworks have each contributed valuable insights into destination competitiveness, many have been developed primarily from a supply side industry stakeholder perspective, omitting the views of travel consumers.

\section{INSERT}

Figure 1. Murphy, Pritchard and Smith (2000) Model of Destination Competitiveness.

For example, an industry stakeholder-based analysis of elements identified in the refined Ritchie and Crouch (2003) model, undertaken by Crouch (2007), found the ten most important attributes of the model to be physiography and climate, market ties, culture and history, tourism superstructure, safety and security, cost/value, accessibility, awareness/image, location and infrastructure. The scope of Crouch's (2007) project did not enable consumers to be directly surveyed. Notwithstanding the value of Crouch's (2007) study, TDC researchers (e.g. Zainuddin, Radzi \& Zahari, 2015; Ferreira \& Pereira, 2014; Hudson, Ritchie \& Timur, 2004; Dwyer \& Kim, 2003) have argued that components of TDC should be measured by direct consumer surveys, rather than indirect measures to provide results well beyond 'indicative' findings which reflect 
the perspectives of the ultimate recipient of tourism - the tourist. With the exception of Cracolici \& Nijkamp, 2005; Kozak \& Rimmington, 1999, few studies have sought to address TDC from a consumer perspective, an undertaking clearly recognised as an important building block in the further practical advancement of this important topic (Dwyer, Livaic \& Mellor, 2003). In this context, it was therefore a key focus of this paper to empirically assess the relative importance of individual attributes of TDC according to a sample of consumers.

\section{Competitiveness and Destination Performance}

Competitiveness is no guarantee of performance (Ritchie \& Crouch, 2003). Destination competitiveness and actual market performance are linked in a number of ways. Destination competitiveness is seen to combine comparative advantages and competitive advantages. Comparative advantage relates to inherited resources such as climate, scenery, flora, fauna, etc., while competitive advantage relates to created items such as tourism superstructure, the quality of management, skills of workers and government policy (Dwyer \& Kim, 2003). The implementation of strategies surrounding these advantages, and their concurrence with destination goals, are then judged by stakeholders and visitors as to the 'success' of the destination (Ritchie \& Crouch, 2003). These strategies, like so many aspects of a destination, however, can be tempered by a destination's stage of development. This research points to the remarks of Haywood (1986), who noted that destination decision-makers need to know what strategic moves are appropriate given each destination life cycle stage situation. As noted previously, integrating a destination's development cycle with the concept of destination competitiveness has the potential to assist destination marketing and management organisations to better devise appropriate management strategies for their destinations as they reach various stages of the life cycle (Ryan, 1991; Buhalis, 2000). Destinations therefore need to take into 
consideration the phase of development they are in, as well as the patterns of destination life cycle experienced in competing destinations, and adopt their strategic marketing accordingly (Buhalis 2000). Tourism life cycle research highlights numerous theoretical and practical implications which are seen to affect the relationship between mature destinations and their less mature counterparts (Diedrich \& Garcia-Buades 2009; Manente \& Pechlaner 2006; Kozak 2004; Sheldon \& Abenoja 2001; Upchurch \& Teivane 2000). The identification of two competing case destinations, proposed as being at differing stages in their development/evolution (developing/consolidating versus mature/signs of stagnation), consequently provides a solid context from which to assess the broader research aim of this paper.

Given the gaps in the existing destination competitiveness literature identified here, this paper aims to provide empirical insights to address the following questions:

- What are the key factors contributing to the competitiveness of tourism destinations from the perspective of the travel consumer?

- What types of capabilities, competencies and resources can assist developing and maturing destinations respectively, in their pursuit of competitiveness?

\section{METHOD}

Prior to the data collection for this particular study, two competing, regional destinations in Australia were chosen as case destinations. The Coffs Coast and Great Lakes tourism regions are both located on the East Coast of New South Wales (NSW) and compete directly with one another within the domestic tourism market. An extensive analysis of tourism strategic plans, 
local government policies, industry focus groups and workshops, national tourism data sets, current marketing activities, and market perceptions associated with each destination, provided initial indications that the two destinations were at differing stages of development. Whilst Butler's (1980) TDLC intended to show the development of a destination in terms of the series of life stages defined principally by infrastructures and number of visitors (Toh, Khan \& Koh 2001), for this study, a combination of statistics and data sources (including population growth rates, employment structures, the type of tourism development etc) in addition to visitors statistics were utilised in an analysis of TDLC indicators (see Tables 2 and 3 respectively), as they relate to both the Great Lakes tourism region (developing destination) and the Coffs Coast (mature destination).

In order to compare the effects of destination stage of development, destinations at the far end of each stage of the tourism destination life cycle were deemed appropriate to include as case studies. The selection of two destinations at polar ends of the TDLC was deemed more manageable to enable comparisons rather than attempting to identify regions at all stages of the life cycle, given that many of these stages are not as distinct as 'developing' versus 'mature'.

\section{INSERT}

Table 2. Destination Stage of Development Indicators of Development/Consolidation ${ }^{1}$

\section{INSERT}

Table 3. Destination Stage of Development Indicators of Maturity/Stagnation ${ }^{2}$

\footnotetext{
${ }^{1}$ Indicators in bold apply to the Great Lakes on the basis of existing data (from Butler 1980; Cooper 1990).

${ }^{2}$ Indicators in bold apply to the Coffs Coast on the basis of existing data (modifications from Butler 1980; Cooper 1990; Morgan 1991; Russell \& Faulkner 1998; Faulkner \& Tideswell 2005).
} 
Preliminary focus groups were held with supply side industry stakeholders in each region to ascertain the respective stages of development of each region and to distinguish the critical attributes which contribute to the tourism competitiveness of each region, deemed to be an essential first step as supported by Crouch (2007). Key findings from these discussions ${ }^{3}$ with destination stakeholders supported the view of Dwyer, Livaic and Mellor (2003) that there is no single set of competitiveness indicators appear to apply to all destinations at all times. In this particular research, broad attributes surrounding natural attractions, uniqueness, variety and value in terms of activities, experiences, products and services; quality infrastructure, tourism stakeholder collaboration, accessibility and destination marketing were accentuated by both regional groups as important elements of destination competitiveness. It is evident that the specific attributes noted by destination stakeholders here are generally acknowledged by other TDC researchers.

Similarities in the views of stakeholders across the two case destinations were apparent, with Coffs Coast being confirmed as a 'mature' destination while Great Lakes was considered a 'developing' region. Data and insights gained from this phase of the research, in collaboration with the key literature sources (i.e. Kim \& Dwyer, 2003; Ritchie, Crouch \& Hudson, 2001) were then used to develop a web-based survey, through which consumers were asked to indicate the relative importance of $38 \mathrm{TDC}$ attributes and indicate how well each of the two destinations were perceived to perform against these attributes.

\footnotetext{
${ }^{3}$ A full set of findings from focus group discussions with industry stakeholders can be found in Wilde \& Cox (2008) and Wilde \& Wray (2012).
} 


\section{Survey Instrument}

The survey instrument was designed in three sections. The first section asked respondents to indicate the how important they believed each of the $38 \mathrm{TDC}$ attributes were to them in relation to each destination. As noted, these attributes were selected following focus group discussions with local tourism industry stakeholders, in collaboration with the key literature sources (Kim \& Dwyer, 2003; Ritchie, Crouch \& Hudson, 2001). Respondents indicated the importance by assigning a value between 1 (not important) and 7 (very important) to each attribute. Importance scales have been used in previous TDC studies to measure attribute significance (Kim \& Dwyer, 2003; Jonkers, 2004; Enright \& Newton, 2004; 2005). In the same way, respondents were then asked to rate the performance of each destination against the TDC attributes on a 7 point scale, where 1 represented 'very poor' and 7 represented 'very good'.

In the second section of the survey, respondents were asked a series of short questions to measure their attitudes towards the stage of development for each of the case destinations. Key destination development/evolutionary terms utilised in question wording, such as 'developing', 'maturity', and 'stagnating', were derived from seminal tourism destination life cycle (TDLC) studies (e.g. Butler, 1980; Haywood, 1986). Demographic information was collected in the final section of the instrument.

\section{Sample and Response Rate}

For a sample of respondents to be contacted, with the support of Coffs Coast Marketing (a destination marketing authority/organisation, or $\mathrm{DMO}$, in one of two respective case 
destinations), potential respondents were invited - via the DMOs regular electronic newsletter to participate in the study in 2010. The electronic mailing list included 2,556 registered contacts. This list included both previous visitors and those individuals who have expressed an interest in learning more about the Coffs Coast. From this mailing list ${ }^{4}$, respondents were recruited. Instructions were included in the electronic invite (to all list members) specifically seeking respondents that had visited both case destinations, thus allowing respondents to provide performance ratings for each destination across the 38 attributes of competitiveness shown in Table 4. As detailed by Kozak (2004), many TDC-related studies provide little evidence about whether respondents have been to sample destinations, and as such, he argues that such studies do not provide a full account of destination competitiveness. Kozak (2004) asserts that it is expected that sample populations should have direct experience in order to respond accurately to all questions regarding their actual tourism experiences with each (research) destination. Otherwise, the findings do not reflect the accurate performance of destinations. Following the electronic invite, 344 useable surveys were received which represents a response rate of 13.6 per cent. This rate is not dissimilar to other web-based surveys (Porter \& Whitcomb, 2003; Dillman et al., 2008).

\section{DATA ANALYSIS AND RESULTS}

\section{Factor Analysis}

In order to discover common underlying factors (or dimensions) of importance within the set of TDC attributes, exploratory factor analysis was utilised. Factor analysis, traditionally, has been

\footnotetext{
4 The second case destination (the Great Lakes) did not maintain a similar mailing list, limiting the researchers' ability to widen the sample. Further, no follow-up questionnaire or e-mail requesting survey completion could be issued as part of an agreement entered into with Coffs Coast Marketing.
} 
used to explore the possible underlying factor structure of a set of observed variables without imposing a preconceived structure on the outcome (Child, 1990). An exploratory, rather than confirmatory approach was taken, as exploratory factor analysis (EFA) is utilised when theoretical knowledge of the data set is minimal, while confirmatory factor analysis (CFA) is employed to test pre-existing theory (Tabachnick \& Fidell, 2001). A number of extant TDC studies have utilised EFA (Dwyer, Mellor, Livaic, Edwards \& Kim, 2004; Bahar \& Kozak, 2007). However, the deployment of factor analysis as an analytical tool can be impacted by a number of commonly cited limitations. The nature of these limitations often stem from the many methodological decisions a researcher must make to complete a single analysis, with the accuracy of the results largely dependent upon the quality of these decisions (Henson \& Roberts, 2006; Tabachnick \& Fidell, 2001). These decisions revolve notably around data assumptions, the adequacy of the sample size, and factor rotation. To first address data assumption issues discussed within factor analysis literature, skewness and kurtosis were verified for the data set. In addition to this analysis, the 5 per cent trimmed mean for each attribute (variable) of competitiveness item was ascertained. The difference between the original mean and the new trimmed mean was very small across the variables utilised in the analysis. Thus, there is a reasonable assumption that normality has been met. Linearity was tested in several ways such as viewing correlation matrices and by generating scatterplots between each pair of variables. Secondly, to the adequacy of the sample size. For the current study, a subject-to-variable ratio of 9 to1 was found, which is considered to be appropriate for factor analysis (Bryant \& Yarnold 1995; Gorsuch, 1983).

Factor analysis of the 38 items was performed using a principal components method followed by a varimax (orthogonal) rotation. Varimax, one of the three major orthogonal approaches (the others being quartimax and equimax), has been shown to be among the best orthogonal rotation 
procedures (Stewart 1981). The principal components analysis identified 8 factors with eigenvalues greater than 1 . These factors explained 61.9 per cent of variance. The scree test of the data was also examined, but appeared to support the notion that only 5 factors should be extracted. Horn's parallel analysis, utilising the Monte Carlo PCA software package, also supported the view that only 5 factors should be extracted. After examining both the 8-factor and 5-factor solutions, it was concluded that the 5-factor solution provided a more meaningful, stable factor solution of which the results are presented in Table 4. Factor loadings of 0.45 were used as a starting point in factor loading interpretation in this research (Hair Jr. et al., 1998; Comrey \& Lee, 1992). Loadings less than 0.45 have been suppressed in Table 4.

An examination of items loaded onto Factor 1 appeared to be consistent with a general theme of destination management. Included in this factor were items such as value for money in destination tourism experiences, attitudes of residents towards visitors, security and safety of visitors, value for money of shopping items, destination's ability to 'listen' to the needs of tourists, quality of tourism/hospitality services, value for money in accommodation, a favourable destination image, variety and quality of accommodation, health and medical facilities, cleanliness, variety of food services (e.g. restaurants), and the availability of tourist information. On the basis of this general theme, this factor was named 'Destination Management (Public and Private)'. Alpha for this factor was calculated to be 0.892 . This is greater than 0.7 , and is therefore considered acceptable (Nunnally \& Bernstein, 1994). Alpha could not be increased by deleting any of the variables from the factor.

Factor 2 contained elements clearly related to facilities and activities, for example, adventure activities, recreation facilities, amusement/fun/theme parks, local public transportation, airport 
quality, night life, special events and festivals, the degree in which you are 'tied' to the destination, variety of shopping outlets, entertainment, sporting facilities, and distance or flying time to the destination from your home. This factor was therefore named 'Facilities and Activities'. Alpha was calculated to be 0.873 . The third factor contains attributes associated with nature based activities (e.g. bushwalking, camping), national parks, accessibility to natural areas, flora and fauna, and natural scenery. This factor was subsequently labelled 'Nature'. Alpha for Factor 3 was calculated to be 0.815 .

Factor 4 contains a number of 'mixed' attributes - items such as variety of cuisine, perceived comfort, climate, breadth of activities for tourists, 'uniqueness' of the destination. The final two items on this factor had loadings close to 0.45 , and thus were maintained. This factor has been labelled 'Augmented Benefits'. Alpha was calculated to be 0.679 , which is close to 0.7 , and is considered acceptable (Moss et al., 1998). The final and fifth factor clearly represents aspects of 'History', with richness of culture and heritage sites loaded on this factor. Alpha was calculated to be 0.772 , and could not be increased by deleting any of the variables from the factor.

To further aid in the interpretation of the EFA results, factor scores were calculated. Factor scores are estimates of the scores subjects would have received on each of the factors had they been measured directly (Hair Jr. et al., 1998). Since orthogonality was maintained, factor scores based on importance (weighted average) were deemed suitable (Hair Jr. et al., 1998), and are therefore presented in Table 5 .

\section{INSERT}

Table 4. Factors of Importance in Tourism Destination Competitiveness 


\section{INSERT}

Table 5. Factor Scores (Weighted Averages) for Attributes of Importance.

\section{Importance-Performance Analysis}

Having identified the critical factors important to consumers when comparing destinations, further analysis was conducted for the two destinations using a method known as ImportancePerformance Analysis (IPA), based on the work of Martilla and James (1977). Martilla and James (1977, p. 77) argued that 'an easily applied technique for measuring attribute importance and performance can further the development of effective marketing programs', a view confirmed by Lovelock, Patterson and Walker (2001) who state that importance-performance analysis is a useful management tool which can help firms to redirect their scarce resources from low impact areas to high impact areas.

To investigate whether the chosen developing and mature destinations performed differently in relation to destination attributes from a consumer perspective, factor scores were plotted against an Importance-Performance grid. The weighted average importance and performance scores for each attribute within the five factors previously reported were calculated and eventually plotted on the IPA grid. The mean factor scores for importance (out of 7) and standard deviations appear previously in Table 4. Similarly, mean factor scores and standard deviations for performance of the case destinations appear below in Table 5.

\section{INSERT}

Table 6. Relative Performance Scores: Coffs Coast (Mature) vs. Great Lakes (Developing) Tourism Regions. 
The average factor ratings of performance for each destination were calculated. The grand means for performance $(\mathrm{x}=5.33)$ and importance $(\mathrm{y}=5.15$; derived from the mean factor scores highlighted in Table 5) determined the placement of axes on the Coffs Coast tourism region IPA grid (Figure 2). Similarly, in assessing the Great Lakes tourism region matrix, grand means for performance $(x=5.07)$ and importance $(y=5.15)$ established the cross hair measure on the second visual grid (Figure 3). Each factor was then assessed according to the quadrant on the grid it is placed.

\section{INSERT}

Figure 2. IPA plot for Coffs Coast Tourism Region (Mature Destination).

\section{INSERT}

Figure 3. IPA plot for Great Lakes Tourism Region (Developing Destination).

Plotting factors into the Importance-Performance matrix reveals that, for the Coffs Coast region, as the mature destination, attributes related to Destination Management (Public and Private), Augmented Benefits and Nature fall into Quadrant 1 (indicating both high importance and high performance). As mentioned by Edward and George (2008), attributes that are rated high in importance and high in performance suggest keeping up the 'good' work and increasing resources directed towards these areas.

In contrast, attributes related to Factor 2 (Facilities and Activities) and Factor 5 (History) received low importance and low performance ratings (Quadrant 3), suggesting that investing resources toward these areas may offer little advantage to the region (Edward \& George, 2008). The 
placement of attributes related to facilities and activities, in addition to elements of history and culture appear less important to consumers, and therefore require less effort as part of the destination's wider development activities, compared to other areas of competitiveness.

Turning attention to the IPA plot for the developing Great Lakes tourism region (Figure 3), the importance and performance analysis for the Great Lakes also positioned key drivers of competitiveness, namely Destination Management (Public and Private), Augmented Benefits and Nature, into Quadrant 1 (high importance and high performance). Further mirroring results from the Coffs Coast, attributes related to Factor 2 (Facilities and Activities) and Factor 5 (History) were also viewed by consumers to be of low importance and low performance in the Great Lakes region (Quadrant 3).

While IPA plots appear to suggest the mature and developing case destinations are no different in terms of relative placement of competitiveness factors, further statistical testing illustrates that some significant differences do in fact exist. A series of paired-samples t tests were conducted to evaluate whether mean performance scores against attributes between the two case destinations, differed statistically across paired dependent variables (the results of which are summarised in Tables 6 \& 7). Using a Bonferroni adjusted alpha of .01, there was a statistically significant increase in performance scores for Factors 1,2 and $4(\mathrm{p}<0.0005)$ for the Coffs Coast when compared to the Great Lakes. For Factor 1 (Destination Management - Public \& Private), the Coffs Coast recorded a mean performance rating of 5.6999, compared to 5.3831 for the Great Lakes. In the case of Factors 2 and 4 (Facilities and Activities; Augmented Benefits), the Coffs Coast recorded a mean performance rating of 4.8946 (Factor 2) and 5.6933 (Factor 4), compared to respective scores of 4.4876 and 5.2994 in the Great Lakes. The eta squared statistic for each 
significant result $(0.30,0.36$ and 0.33$)$, indicates that the difference between mean performance scores on Factors 1, 2 and 4 (between the Coffs Coast and Great Lakes tourism regions) are of a large effect (Cohen, 1988).

INSERT
Table 7. Summary of Results - Paired-Samples t tests.

\section{DISCUSSION AND IMPLICATIONS}

The exploratory factor analysis highlighted a number of interesting findings. Firstly, respondents clearly differentiate those management attributes commonly categorised by the literature (as being under the control of a destination, from other aspects or strategies that might also underpin the competitiveness of a destination (Ritchie \& Crouch, 2003; Dwyer, Livaic \& Mellor, 2003; Dwyer \& Kim, 2003; Enright \& Newton, 2005). The significance of those management activities required in 'managing' a destination is a focal point within seminal TDC literature and it appears that these activities continue to provide an important policy foundation within the competitive tourism environment (Ritchie \& Crouch, 1993; Poon, 1993).

This conclusion is further underpinned by consumers who indicated that these managementrelated attributes are most important in their minds (providing a mean factor score of 5.9544 on a 7-point scale). Destination management factors are considered by the literature to be those factors that play a critical role in 1) enhancing the appeal of a destination's core resources and attractors, 2) strengthening the quality and effectiveness of the supporting factors and resources and 3) provide a strong foundation from which a destination can best adapt to situational 
conditions (Crouch \& Ritchie, 1999; Dwyer \& Kim, 2003). The high mean factor score provided by consumers in this research effort appears to empirically support this conceptual notion.

Further to this, consumers did not generally distinguish between destination management activities that are primarily the responsibility of the public sector (survey items, for example, like security and safety of visitors, health and medical facilities, cleanliness, the availability of tourist information etc) from those features that are predominantly the responsibility of private sector operators (such as quality of tourism/hospitality services, variety of food services, value for money of shopping items etc). As noted by Heath (2003), every destination is comprised of many public and private sector 'actors' all who have the potential to add value to the overall competitiveness of the destination. Tourism-related activities commonly attributed to the public sector include the development of national tourism strategies; tasks involved in destination management (including the coordination of a destination marketing authority, the provision of information, strategy monitoring and evaluation); destination marketing; destination policy, planning, and development; human resource development; and environmental management. Activities associated with the private tourism sector include those of tourism/hospitality industry associations; industry involvement in and funding of destination marketing programs; industry training programs; industry adoption of 'green' tourism operations; new product development; environmental certification programs, and so forth (Dwyer \& Kim, 2003). In practice, however, the multiplicity of players (both public and private) in the tourism industry can create difficulties in effectively building and conveying a vision within an often fragmented industry landscape (Wilde \& Wray, 2012). The growing literature related to destination competiveness confirms that collaboration and developing sound destination management structures are an important element to achieve competitive advantage (Dwyer, Liviac, \& Mellor, 2003; Ritchie \& Crouch, 2003). 
The factor analysis further indicates that respondents linked a series of recreational facilities and activities. It is clear that attributes loaded against Factor 2 have the potential to become strong 'pull' factors for visitors. According to Yoon and Uysal (2005), pull motivations such as recreation facilities, entertainment, shopping, and parks play a critical role in enhancing a destination's attractiveness. The findings of the current research supports this assertion, as recognised by attributes loaded onto Factor 2. A third group of items (which have been labelled 'Nature') contained attributes associated with nature based activities. This factor was credited with a relatively high importance rating by respondents (mean factor score -5.3291 ). Because so much of the tourism experience is associated with the physical resources of a destination, environment-related aspects of destination can be 'so important that it dominates other factors of competitiveness' (Ritchie \& Crouch, 2010, p. 1054). The importance of these attributes is further supported by the work of Hassan (2000), Kozak \& Rimmington (1999), Dwyer \& Kim (2003), and Omerzel (2005), who all advocate nature-based elements of competitiveness. Like manmade activities these results point to the need to maintain robust environmental strategies for the tourism industry.

Of the remaining factors, items loaded against Factor 4 'augmented benefits' whilst not viewed as 'core' to the competitiveness of a destination (such as climate and perceived comfort), provide additional value to the customer's purchase - these attributes provide 'that little extra'. The loading of the remaining item (such as variety of cuisine, breadth of activities for tourists, 'uniqueness' of the destination) onto this factor as opposed to other factors was somewhat unexpected. In considering these three mixed attributes, we can draw a conclusion that these attributes relate to the notion of adding the elements of comfort of a destination, represented as 'augmented benefits'. 
Given that the examination of principal attributes contributing to the competitiveness of tourism destinations, when the stage of development or evolution of a destination is considered, appears to have 'been totally neglected by tourism researchers to date' (Dwyer \& Kim 2003, p. 406), a number of revealing conclusions can be drawn from the IPA and significance testing results. Firstly, as highlighted by Enright and Newton (2004), an important caveat should be added when considering factors that fall into the IPA quadrants that denote low importance. It is possible that whilst these factors, such as 'History' in this study, are necessary factors for the overall competitiveness of a destination (Heath, 2003; Dwyer \& Kim; 2003; Ritchie \& Crouch, 2003; Crouch, 2007); tourists may not actually recognise them, and in cases where such attributes are not present, then it might generate dissatisfaction (Enright \& Newton, 2004). A recent tourism industry profile of both case destinations failed to identify any distinctive cultural elements relevant to the case regions. Thus, from a case destination perspective, the placement of this factor in Quadrant 2 appears warranted. Nonetheless, the potential to attract particular segments of tourists with high preference for these features could be an avenue which could be further explored and researched in the case destination regions.

Secondly, whilst developing destinations have been seen to threaten mature destinations (Diedrich \& Garcia-Buades, 2009; Kozak, 2004; Manente \& Pechlaner, 2006; Sheldon \& Abenoja, 2001), the results in this paper indicate that in terms of attribute performance, relative destination immaturity may well constrain a developing destination's ability to satisfy the needs of both principal and emerging markets. Whilst tourism was not defined by Great Lakes stakeholders as being in its infancy locally, it appears that some significant issues (for example, Great Lakes stakeholders identified issues such as a critical need for sound planning and development strategies; development of quality accommodation and other tourism infrastructure; 
the development of an industry vision etc) exist in developing destinations, and that these matters must be effectively and appropriately responded to by industry stakeholders, in order to take advantage of potential growth opportunities. Importantly however, the extant tourism life cycle literature proposes that the development phase of a destination's life cycle provides a critical period during which time a location can shape its future as a tourism destination (Upchurch \& Teivane, 2000). Therefore, stakeholders in a developing destination can continue to dictate (to a significant extent) the development and positioning of their destination, with particular reference to destination management activities (both public and private), which were considered by consumers to be the most important attributes of destination competitiveness.

To conclude this section, by linking key attributes of competitiveness with ratings of consumer importance and perceived destination performance, this research has drawn some focus towards the ability of two case destinations (identified as being at differing stages of development) to meet visitor expectations and therefore ensure their appeal to key segments. A careful appraisal of destination attributes where performance may be deficient has the potential to offer stakeholders several directions for development focus, in order to better support the needs of visitors. In terms of those aspects of the tourism experience considered to be important by tourists, the mature Coffs Coast tourism region performed at a higher level across some determinants of competitiveness relative to a main developing competitor, the Great Lakes tourism region. The results provide prima-facie support for the notion (mentioned previously) that, in terms of attribute performance, relative destination immaturity may possibly limit a developing destination's ability to satisfy the needs of targeted consumer markets. 


\section{CONCLUSION AND LIMITATIONS}

The results obtained using Exploratory Factor Analysis (EFA) linked individual TDC attributes, in the minds of the respondents, into five factors. These factors were labelled: Destination Management (Public and Private), Facilities and Activities, Nature, Augmented Benefits and History. As stated by Dwyer and Kim (2003), TDC is intrinsically linked to the relative ability of a destination to perform better than other destinations on those aspects of the tourism experience considered to be important by tourists. The use of an importance-performance analysis assisted this research in generating TDC findings across a much broader foundation. For industry professionals engaged in the marketing and management of tourism destinations, a string of implications for managerial practice can be derived from the results reported in this paper. This research demonstrates that there may be considerable practical value in placing particular emphasis on different competitiveness attributes. By allowing for the integration of a destination's evolutionary cycle into competitiveness-based strategies; or put another way, by viewing destination competitiveness through an evolutionary prism; destination managers may be better able to steer their strategies towards a more focused, destination specific conclusion.

Like all research, the limitations associated with this study must be acknowledged. It is recognised in this paper that no universal set of items, attributes or indicators used to measure the competitiveness of tourism destinations exists (Dwyer, Livaic \& Mellor, 2003). The variety of attributes or indicators adopted by TDC researchers in the field are testament to this. Other attributes or indicators not discussed or measured as part of this study may be present. A second limitation of this research relates to sampling. The degree of fit between a sample and the target population about which generalisations can be made is a common challenge in many studies, but 
this shortcoming does not restrict the chosen medium as a data-gathering device or the respondents to Internet methodologies as any more or less useful as any other sample (Walther, 2002). While the research context refers to two specific case study destinations, and the findings cannot be extended to all regional destinations as such, the methods used to add to the understanding of destination competiveness are readily transferable to other tourism regions. The addition of consumer insight towards the study of destination competitiveness is a valuable contribution to the field and future studies which embed the views of this important stakeholder group are warranted, as are endevours to understand how competitiveness factors may differ between destinations at varying stages of development. In the current research, qualitative (focus group) and quantitative (web-survey) data was collected over a relative short timeframe. Other researchers may find value in increasing future TDC studies in terms of longitudinal characteristics, thus making it possible to analyse the contribution of TDC attributes over longer periods of time. 


\section{REFERENCES}

Bahar, O., \& Kozak, M. (2007). Advancing Destination Competitiveness Research: Comparison Between Tourists and Service Providers. Journal of Travel and Tourism Marketing, 22(2), 61-71.

Buhalis, D. (2000). Marketing the competitive destination of the future. Tourism Management, 21, 97-116.

Butler, R. (1980). The concept of the tourist area lifecycle of evolution: implications for the management of resources. Canadian Geographer, 24, 5-12.

Bryant, F.B., \& Yarnold, P.R. (1995), Principal components analysis and exploratory and confirmatory factor analysis. In Grimm, L.G. and Yarnold, P.R. (ed.) Reading and understanding multivariate analysis, American Psychological Association Books, Washington DC, pp. 99-136.

Child, D. (1990). The essentials of factor analysis (2nd ed.). London: Cassel Educational Limited.

Cohen, J. (1988). Statistical power analysis for the behavioral sciences (2nd ed.). Hillsdale, NJ: Lawrence Earlbaum Associates.

Comrey, A.L., \& Lee, H.B. (1992). A first course in factor analysis, Hillsdale, New Jersey: Erlbaum.

Cooper, C.P. (1990), Resorts in Decline: the Management Response. Tourism Management, 11(1), 63-67.

Cracolici, M.F. \& Nijkamp, P. (2005). Attractiveness and Effectiveness of Competing Tourist Areas: A Study on Italian Provinces. Serie Research Memoranda 0009, available at http://ideas.repec.org/p/dgr/vuarem/2005-9.html.

Crompton, J.L., \& Duray, N.A. (1985). An investigation of the relative efficacy of four alternative approaches to importance-performance analysis. Journal of the Academy of Marketing Science, 13(4), 69-80.

Crouch, G.I. (2007). Modelling Destination Competitiveness: A Survey and Analysis of the Impact of Competitiveness Attributes. Melbourne: La Trobe University.

Crouch, G.I., \& Ritchie, J.R.B. (1999). Tourism, competitiveness, and societal prosperity. Journal of Business Research, 44, 137-152.

Diedrich, A., \& Garcia-Buades, E. (2009). Local perceptions of tourism as indicators of destination decline. Tourism Management, 30, 512-521.

Dillman, D.A., Phelps, G., Tortora, R., Swift, K., Kohrell, J., \& Berck, J. (2008). Response Rate and Measurement Differences in Mixed Mode Surveys Using Mail, Telephone, Interactive Voice Response and the Internet, Washington State University Social and Economic Sciences Research Centre Working Paper, Washington State University, Pullman, Washington.

Dwyer, L., \& Kim, C. (2003). Destination Competitiveness: determinants and indicators. Current Issues in Tourism, 6(5), 369-414.

Dwyer, L., Livaic, Z., \& Mellor, R. (2003). Competitiveness of Australia as a tourist destination. Journal of Hospitality and Tourism Management, 10(1), 60-79. 
Dwyer, L., Mellor, R., Livaic, Z., Edwards, D., \& Kim, C. (2004). Attributes of Destination Competitiveness: A Factor Analysis. Tourism Analysis, 9, 91-101.

Edward, M., \& George, P.B. (2008). Destination Attractiveness of Kerala as an International Tourist Destination: An Importance-Performance Analysis. Paper presented at the Tourism in India - Challenges Ahead, Kozhikode, India.

Enright, M.J., \& Newton, J. (2004). Tourism destination competitiveness: a quantitative approach. Tourism Management, 25, 777-788.

Enright, M.J., \& Newton, J. (2005). Determinants of Tourism Destination Competitiveness in Asia Pacific: Comprehensiveness and Universality. Journal of Travel Research, 43, 339-350.

Faulkner, B. \& Tideswell, C. (2005), Rejuvenating a Maturing Tourist Destination: The Case of the Gold Coast, Australia. In Butler, R. (ed.) The Tourism Area Life Cycle: Applications and modifications, Vol. 1, Channel View Publications, Clevedon, UK.

Faulkner, B., Oppermann, M., \& Fredline, E. (1999). Destination competitiveness: An exploratory examination of South Australia's core attractions. Journal of Vacation Marketing, 5(2), 125-139.

Ferreira1, L.N., \& Pereira, L.N. (2014). 'Measuring Tourists' Preferences - Which Road to Choose?', Journal of Tourism and Hospitality, 3, available at http://omicsgroup.org/journals/measuring-tourists-preferences-which-road-to-choose-21670269.1000e130.php?aid=30124

Gooroochurn, N., \& Sugiyarto, G. (2004). Measuring Competitiveness in the Travel and Tourism Industry TTRI Discussion Paper Series. Nottingham, UK: University of Nottingham.

Gorsuch, R.L. (1983). Factor Analysis, Lawrence Erlbaum: Hillsdale, USA.

Hair Jr., J.F., Anderson, R.E., Black, W.C., \& Tatham, R.L. (1998). Multivariate Data Analysis. Upper Saddle River: Prentice Hall.

Hassan, S.S. (2000). Determinants of Market Competitiveness in an Environmentally Sustainable Tourism Industry. Journal of Travel Research, 38(February), 239-245.

Haywood, K.M. (1986). Can the Tourist-Area Life Cycle Be Made Operational. Tourism Management, 7(3), 154-167.

Heath, E. (2003). Towards a model to enhance destination competitiveness: A Southern African perspective. Paper presented at the CAUTHE 2003 National Research Conference, Coffs Harbour, Australia, 5-8 February.

Henson, R.K. \& Roberts, J.K. (2006). Use of exploratory factor analysis in published research: common errors and some comment on improved practice. Educational and Psychological Measurement, 66, 393-416.

Hudson, S., Ritchie, B., \& Timur, S. (2004). Measuring Destination Competitiveness: An Empirical Study of Canadian Ski Resorts. Tourism and Hospitality: Planning \& Development, 1(1), 79-94.

Jonkers, J. (2004). The Strategic Identification and Integration of Critical Success Factors to Achieve International Competitiveness for South Africa as a Tourism Destination. University of Pretoria, Pretoria, South Africa. 
Kim, C., \& Dwyer, L. (2003). Destination competitiveness and bilateral tourism flows between Australia and Korea. Journal of Tourism Studies, 14(2), 55-67.

Kozak, M. (2004). Destination Benchmarking: Concepts, Practices and Operations. Wallingford, Oxon: CABI.

Kozak, M., \& Rimmington, M. (1999). Measuring tourist destination competitiveness: conceptual considerations and empirical findings. International Journal of Hospitality Management, 18(3), 273-283.

Lee, C. \& King, B. (2006). Assessing Destination Competitiveness: An Application to the Hot Springs Tourism Sector. Tourism and Hospitality: Planning and Development, 3, 179-197.

Leung, X., and Baloglu, S. (2013). Tourism Competitiveness of Asia Pacific Destinations. Tourism Analysis, 18(4), 371-384.

Lovelock, C., Patterson, P., \& Walker, R. (2001). Services Marketing an Asia-Pacific Perspective. Sydney, Australia: Pearson.

Manente, M., \& Pechlaner, H. (2006). How to Define, Identify and Monitor the Decline of Tourist Destinations: Towards an Early Warning System. In R. Butler (Ed.), The Tourism Area Life Cycle: Conceptual and Theoretical Issues. Clevedon, USA: Channel View Publications.

Martilla, J., \& James, J. (1977). Importance-Performance Analysis. Journal of Marketing, 41(1), 77-79.

Morgan, M. (1991), Dressing up to Survive: Marketing Majorca a New. Tourism Management, $12,15-20$.

Moss, S., Prosser, H., Costello, H., Simpson, N., Patel, P., Rowe, S., Turner, S. \& Hatton C. (1998). Reliability and validity of the PAS-ADD Checklist for detecting psychiatric disorders in adults with intellectual disability. Journal of Intellectual Disability Research, 42, 173-183.

Murphy, P., Pritchard, M.P., \& Smith, B. (2000). The destination product and its impact on traveller perceptions. Tourism Management, 21, 43-52.

Nunnally, J.C., \& Bernstein, I.H. (1994). Psychometric Theory. New York, USA: McGraw-Hill.

Omerzel, D.G. (2005). Competitiveness of Slovenia as a tourist destination. Paper presented at the 6th International Conference of the Faculty of Management Koper, Portorož, Slovenia, 24-26 November.

Poon, A. (1993). Tourism, Technology, and Competitive Strategy. Wallingford, UK: CAB International.

Porter, M.E. (1979). How competitive forces shape strategy. Harvard Business Review, 57(2), $137-145$.

Porter, S.R., \& Whitcomb, M.E. (2003). The Impact of Contact Type on Web Survey Response Rates. Public Opinion Quarterly, 67(4), 579-588.

Prideaux, B., Berbigier, D., \& Thompson, M. (2013). Wellness tourism and destination competitiveness. In C. Pforr \& C. Voigt (Eds.), Wellness tourism - a destination perspective. Abingdon, UK: Routledge.

Ritchie, B., Crouch, G.I., \& Hudson, S. (2001). Developing Operational Measures for the 
Components of a Destination Competitiveness/Sustainability Model: Consumer versus Managerial Perspectives. In G. I. e. a. Crouch (Ed.), Consumer Psychology of Tourism, Hospitality and Leisure (Vol. 2, pp. 368). Wallingford, UK: CABI.

Ritchie, J.B.R., \& Crouch, G.I. (1993). Competitiveness in International Tourism: A Framework for Understanding and Analysis. Paper presented at the 43rd Congress of the Association Internationale d'Experts Scientifique du Tourisme, San Carlos de Bariloche, Argentina, 17-23 October.

Ritchie, J.R.B. \& Crouch, G.I. (2010). A model of destination competitiveness/sustainability: Brazilian perspectives. Brazilian Public Administration Review, 44(5), 1049-66.

Ritchie, J.R.B., \& Crouch, G.I. (2000). Are destination stars born or made: must a competitive destination have star genes? Paper presented at the 31st Annual Conference of Travel and Tourism Research Association San Fernando Valley, CA.

Ritchie, J.R.B., \& Crouch, G.I. (2003). The Competitive Destination: A Sustainable Tourism Perspective. Wallingford, Oxon, UK.: CABI Publishers.

Russell, R. \& Faulkner, B. (1998), Reliving the Destination Life Cycle in Coolangatta: An Historical Perspective on the Rise, Decline, and Rejuvenation of an Australian Seaside Resort. In Laws, E., Faulkner, B. and Moscardo, G. (ed.) Embracing and Managing Change in Tourism: International Case Studies, Routledge, London, UK.

Ryan, C. (1991). Tourism and marketing-A symbiotic relationship. Tourism Management, 12(2), $101-111$.

Sheldon, P.J., \& Abenoja, T. (2001). Resident attitudes in a mature destination: the case of Waikiki. Tourism Management, 22, 435-443.

Stewart, D. (1981). The Application and Misapplication of Factor Analysis in Marketing. Journal of Marketing Research, 18(1), 51-62.

Tabachnick, B.G., \& Fidell, L.S. (2001). Using Multivariate Statistics (4th ed.). New Jersey, USA: Allyn \& Bacon.

Toh, R.S., Khan, H., \& Koh, A.J. (2001), A Travel Balance Approach for Examining Tourism Area Life Cycles: The Case of Singapore. Journal of Travel Research, 39(4), 426-432.

Upchurch, R.S., \& Teivane, U. (2000). Resident perceptions of tourism development in Riga, Latvia. Tourism Management, 21, 499-507.

Walther, J.B. (2002). Research ethics in Internet-enabled research: Human subjects issues and methodological myopia. Ethics and Information Technology, 4, 205-216.

Wilde, S., \& Cox, C. (2008). Linking Destination Competitiveness and Destination Development: Findings from a Mature Australian Tourism Destination, Paper presented at the Travel and Tourism Research Association (TTRA) European Chapter Conference - Competition in Tourism: Business and Destination Perspectives, Helsinki (Finland), April 23-25.

Wilde, S., \& Wray, M. (2012). An Exploratory Study of Management and Competitiveness Factors for Developing Destinations: An Australia Case, Paper presented at the 2012 Academy of World Business, Marketing \& Management Development Conference, Budapest (Hungary), 1619 July. 
Yoon, Y., \& Uysal, M. (2005). An examination of the effects of motivation and satisfaction on destination loyalty: a structural model. Tourism Management, 26(1), 45-56.

Zainuddin, Z., Radzi, S.M., \& Zahari, M. (2015), Tourists perceived destination competitiveness: a case of Langkawi Island, Malaysia. In Radzi, S. et al. (ed.) Theory and Practice in Hospitality and Tourism Research, CRC Press/Taylor and Francis, London, United Kingdom, pp. 289-297.

\section{ACKNOWLEDGMENTS}

The Sustainable Tourism Cooperative Research Centre, established and supported under the Australian Government's Cooperative Research Centres Programme, funded this research through a Joint PhD Scholarship. Furthermore, this paper is an extension of one presented and published at the 16th Annual Asia Pacific Tourism Association (APTA) Conference, Macau S.A.R (China). The authors would like to thank conference participants for their feedback on the original paper and concepts. 


\section{TABLES AND FIGURES}

Table 1. The Calgary Model of Competitiveness in Tourism -

Factors of Destination Competitiveness

\begin{tabular}{|l|l|l|l|l|}
\hline $\begin{array}{l}\text { Destination } \\
\text { Appeal }\end{array}$ & $\begin{array}{l}\text { Destination } \\
\text { Management }\end{array}$ & $\begin{array}{l}\text { Destination } \\
\text { Organisation }\end{array}$ & $\begin{array}{l}\text { Destination } \\
\text { Information }\end{array}$ & $\begin{array}{l}\text { Destination } \\
\text { Efficiency }\end{array}$ \\
\hline $\begin{array}{l}\text { ATTRACT } \\
\begin{array}{l}\text { Destination } \\
\text { Attractiveness }\end{array}\end{array}$ & $\begin{array}{l}\text { MANAGER } \\
\text { Managerial } \\
\text { Efforts }\end{array}$ & $\begin{array}{l}\text { DMO } \\
\text { Management } \\
\text { organisation } \\
\text { capabilities }\end{array}$ & $\begin{array}{l}\text { MIS } \\
\text { Internal } \\
\text { management } \\
\text { information system }\end{array}$ & $\begin{array}{l}\text { Integrity of } \\
\text { experience }\end{array}$ \\
$\begin{array}{l}\text { DETER } \\
\begin{array}{l}\text { Destination } \\
\text { deterrents }\end{array}\end{array}$ & $\begin{array}{l}\text { MKGT } \\
\text { efforts }\end{array}$ & $\begin{array}{l}\text { ALLIANCE } \\
\text { Strategic } \\
\text { alliances }\end{array}$ & $\begin{array}{l}\text { RESEARCH } \\
\text { Research } \\
\text { capabilities }\end{array}$ & PROD \\
\hline
\end{tabular}

Source: Ritchie \& Crouch 1993, p. 48.

Figure 1. Murphy, Pritchard and Smith (2000) Model of Destination Competitiveness.

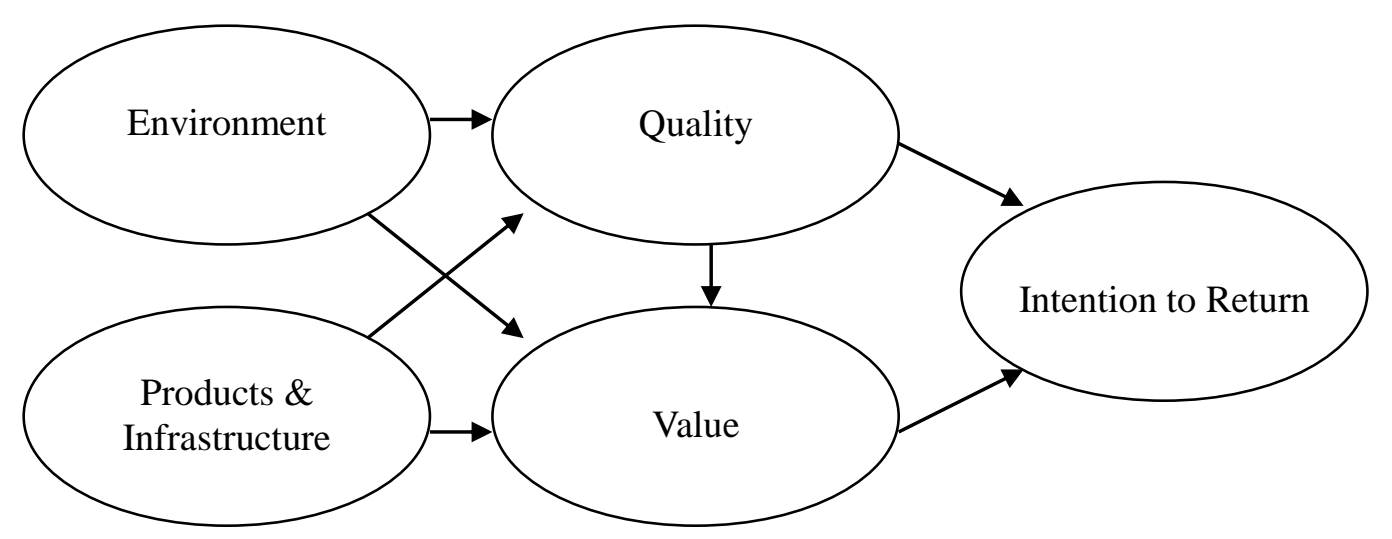


Table 2. Destination Stage of Development Indicators of Development/Consolidation

\begin{tabular}{|l|l|}
\hline \multicolumn{1}{|c|}{ Area of destination performance } & \multicolumn{1}{c|}{ Indicators } \\
\hline 1. Tourism market & $\begin{array}{l}\text { - Tourism market is well-defined } \\
\text { - Efforts are being made to extend the tourism } \\
\text { season }\end{array}$ \\
\begin{tabular}{|l|l|} 
- Rate of increase in numbers of tourists will decline \\
although total numbers with still increase \\
- Total visitor numbers exceed the number of \\
permanent residents
\end{tabular} \\
\hline 2. Facilities and control & $\begin{array}{l}\text { Local involvement declines as they lose control } \\
\text { of development }\end{array}$ \\
$\begin{array}{l}\text { - External organisations will replace local } \\
\text { provided facilities with larger, more elaborate } \\
\text { and modern facilities }\end{array}$ \\
\hline - Overuse and deterioration of facilities \\
\hline 3. Economic impact & $\begin{array}{l}\text { - Economy of the region is now dependent on } \\
\text { tourism }\end{array}$ \\
\hline $\begin{array}{l}\text { - Heavy marketing and advertising will be } \\
\text { extensive }\end{array}$ \\
$\begin{array}{l}\text { - Opposition and feelings of discontent are evident } \\
\text { among the host community }\end{array}$ \\
\hline
\end{tabular}


Table 3. Destination Stage of Development Indicators of Maturity/Stagnation

\begin{tabular}{|c|c|}
\hline Area of destination performance & Indicators \\
\hline 1. Changing markets & $\begin{array}{l}\text { - Growth in low-status, low-spend visitors and day } \\
\text { visitors } \\
\text { - Overdependence on long-haul market } \\
\text { - Emphasis on high-volume, low-yield inclusive tour } \\
\text { market } \\
\text { - A decline in visitors length of stay } \\
\text { - Type of tourists increasingly organised mass tourists } \\
\text { - A declining proportion of first-time visitors, as } \\
\text { - Lpposed to repeat visitors } \\
\text { - Himited or declining appeal to overseas visitors } \\
\text { Highly seasonal }\end{array}$ \\
\hline 2. Emerging newer destinations & $\begin{array}{l}\text { - Competition from emerging newer destinations } \\
\text { - The destination is well known, but no longer } \\
\text { fashionable }\end{array}$ \\
\hline 3. Infrastructure & $\begin{array}{l}\text { - Outdated, poorly maintained accommodation } \\
\text { and amenities } \\
\text { - Older properties are changing hands and newer } \\
\text { properties, if they are being built are on the } \\
\text { periphery of the original tourist areas } \\
\text { - Market perceptions of the destination becoming } \\
\text { overcommercialised, crowded and 'tacky' } \\
\text { - Diversification into conventions and conferences to } \\
\text { maintain numbers } \\
\text { - Large number of man-made attractions, which start } \\
\text { to outnumber the more natural attractions that made } \\
\text { the place popular in the first place }\end{array}$ \\
\hline 4. Business performance & $\begin{array}{l}\text { - Declining profits of major tourism businesses } \\
\text { - Lack of confidence in the tourism business } \\
\text { community } \\
\text { - A decline in the elasticity of advertising } \\
\text { - Lack of professional, experienced staff }\end{array}$ \\
\hline $\begin{array}{l}\text { 5. Social and environmental carrying } \\
\text { capacities }\end{array}$ & $\begin{array}{l}\text { - Visitor levels approaching or exceeding social and } \\
\text { environmental carrying capacities } \\
\text { - Local opposition to tourism as the resort's } \\
\text { (destination) residential role increases }\end{array}$ \\
\hline 6. Institutional environment & $\begin{array}{l}\text { - Local government reorganisation } \\
\text { (amalgamation) diluting the political power of } \\
\text { resorts (destinations) in larger authorities } \\
\text { - Demands for increased operational efficiency and } \\
\text { entrepreneurial activity in local government } \\
\text { - Short-term planning horizons in local government } \\
\text { owing to financial restrictions and a low priority } \\
\text { given to strategic thinking } \\
\text { - Shortage of research data }\end{array}$ \\
\hline
\end{tabular}


Table 4. Factors of Importance in Tourism Destination Competitiveness

\begin{tabular}{|c|c|c|c|c|c|c|}
\hline Attributes of Tourism Destination Competitiveness & 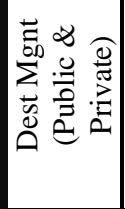 & 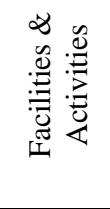 & $\begin{array}{l}\stackrel{\circlearrowright}{E} \\
\text { Z }\end{array}$ & 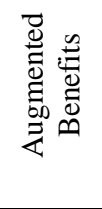 & 总 & 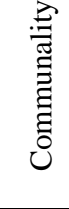 \\
\hline Value for money in destination tourism experiences & .707 & & & & & .577 \\
\hline Attitudes of residents towards visitors & .688 & & & & & .552 \\
\hline Security and safety of visitors & .684 & & & & & .513 \\
\hline Value for money of shopping items & .666 & & & & & .551 \\
\hline Destination's ability to 'listen' to the needs of tourists & 659 & & & & & .531 \\
\hline Quality of tourism/hospitality services & 610 & & & & & .550 \\
\hline Value for money in accommodation & .591 & & & & & .444 \\
\hline A favourable destination image & .581 & & & & & .451 \\
\hline Variety and quality of Accommodation & .575 & & & & & .609 \\
\hline Health and medical facilities & .575 & & & & & .515 \\
\hline Cleanliness & .513 & & & & & .515 \\
\hline Variety of food services (e.g. Restaurants) & .463 & & & & & .523 \\
\hline Availability of tourist information & .460 & & & & & .399 \\
\hline Adventure activities (e.g. rafting, skydiving) & & .730 & & & & .613 \\
\hline Recreation facilities (e.g. parks, leisure facilities, horseriding) & & .723 & & & & .572 \\
\hline Amusement/Fun/Theme parks & & 665 & & & & .540 \\
\hline Local public transportation & & 653 & & & & .581 \\
\hline Airport quality & & 631 & & & & .533 \\
\hline Night life (e.g. bars, clubs) & & 628 & & & & .507 \\
\hline Special events and festivals & & 620 & & & & .505 \\
\hline The degree in which you are 'tied' to the destination & & .578 & & & & .499 \\
\hline Variety of shopping outlets & & .520 & & & & .520 \\
\hline Entertainment (e.g. theatres, galleries, cinemas) & & .497 & & & & .410 \\
\hline Sporting facilities (e.g. golf, tennis) & & .482 & & & & .599 \\
\hline Distance or flying time to the destination from your home & & .472 & & & & .289 \\
\hline Nature based activities (e.g. bushwalking, camping) & & & .778 & & & .666 \\
\hline National Parks & & & .775 & & & .638 \\
\hline Accessibility to natural areas & & & .739 & & & .639 \\
\hline Flora and fauna & & & 681 & & & .586 \\
\hline Natural Scenery & & & 640 & & & .563 \\
\hline Variety of cuisine & & & & .702 & & .579 \\
\hline Perceived Comfort & & & & .600 & & .564 \\
\hline Climate & & & & .554 & & .431 \\
\hline Breadth of activities for tourists & & & & .441 & & .427 \\
\hline 'Uniqueness' of the destination & & & & .404 & & .385 \\
\hline Richness of Culture & & & & & .715 & .682 \\
\hline Heritage sites & & & & & .587 & .572 \\
\hline Water based activities (e.g. swimming, surfing, boating, fishing) & & & & & & .531 \\
\hline$\%$ of Variance & 15.338 & 14.648 & 9.665 & 8.438 & 4.977 & \\
\hline Eigenvalue & 10.456 & 3.515 & 2.888 & 1.739 & 1.567 & \\
\hline Cronbach Alpha & 0.892 & 0.873 & 0.815 & 0.679 & 0.772 & \\
\hline
\end{tabular}


Table 5. Factor Scores (Weighted Averages) for Attributes of Importance.

\begin{tabular}{|c|c|c|}
\hline Factor Name & Mean & Std. Dev \\
\hline $\begin{array}{c}\text { Destination Management } \\
\text { (Public \& Private) }\end{array}$ & 5.9544 & 0.76962 \\
\hline Facilities and Activities & 4.2180 & 1.13169 \\
\hline Nature & 5.3291 & 0.9919 \\
\hline Augmented Benefits & 5.7020 & 0.76257 \\
\hline History & 4.5349 & 1.19166 \\
\hline
\end{tabular}

Table 6. Relative Performance Scores: Coffs Coast (Mature) vs. Great Lakes (Developing) Tourism Regions.

\begin{tabular}{|c|c|c|c|c|}
\hline & \multicolumn{2}{|c|}{ Coffs Coast (Mature) } & \multicolumn{2}{c|}{ Great Lakes (Developing) } \\
\hline Factor Name & Mean & Std. Dev & Mean & Std. Dev \\
\hline $\begin{array}{c}\text { Destination Management } \\
\text { (Public \& Private) }\end{array}$ & 5.6999 & 0.74536 & 5.3831 & 0.80967 \\
\hline Facilities and Activities & 4.8946 & 0.94597 & 4.4876 & 0.95418 \\
\hline Nature & 5.7128 & 0.82417 & 5.6297 & 0.92780 \\
\hline Augmented Benefits & 5.6933 & 0.68383 & 5.2994 & 0.77551 \\
\hline History & 4.6366 & 1.11520 & 4.5451 & 1.11451 \\
\hline
\end{tabular}


Figure 2. IPA plot for Coffs Coast Tourism Region (Mature Destination).

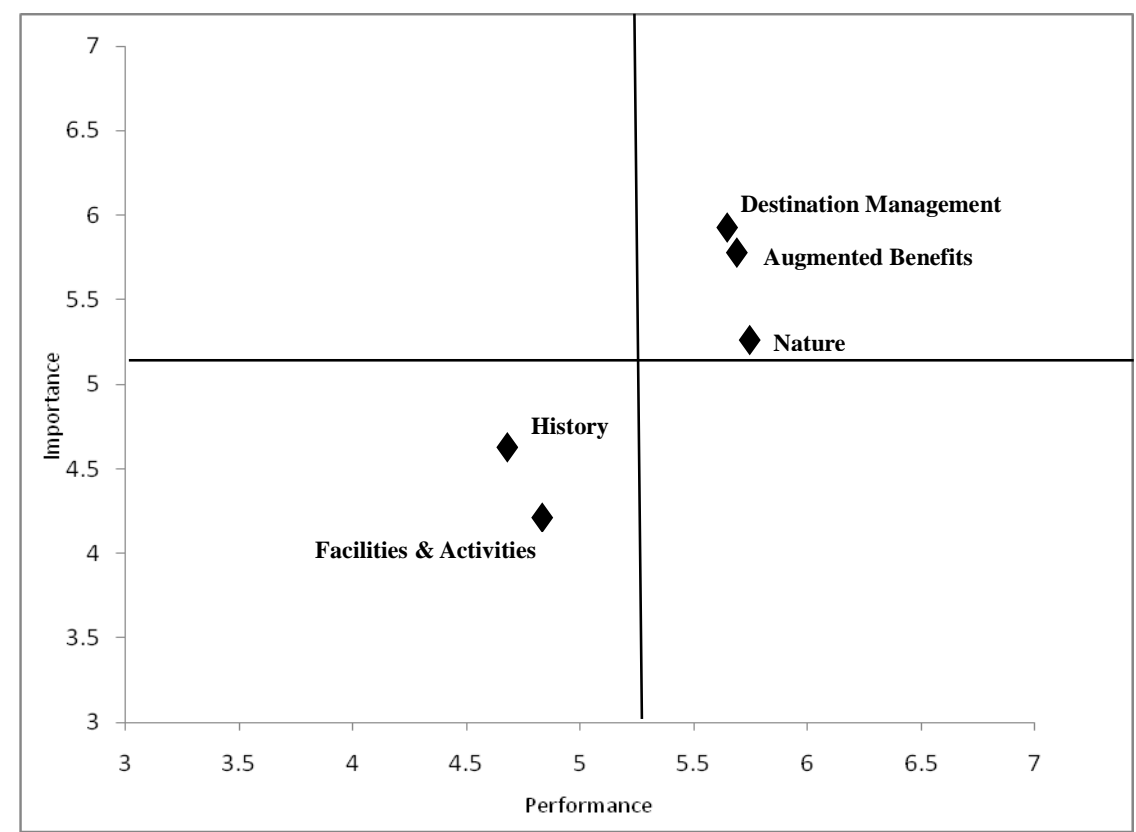

Figure 3. IPA plot for Great Lakes Tourism Region (Developing Destination).

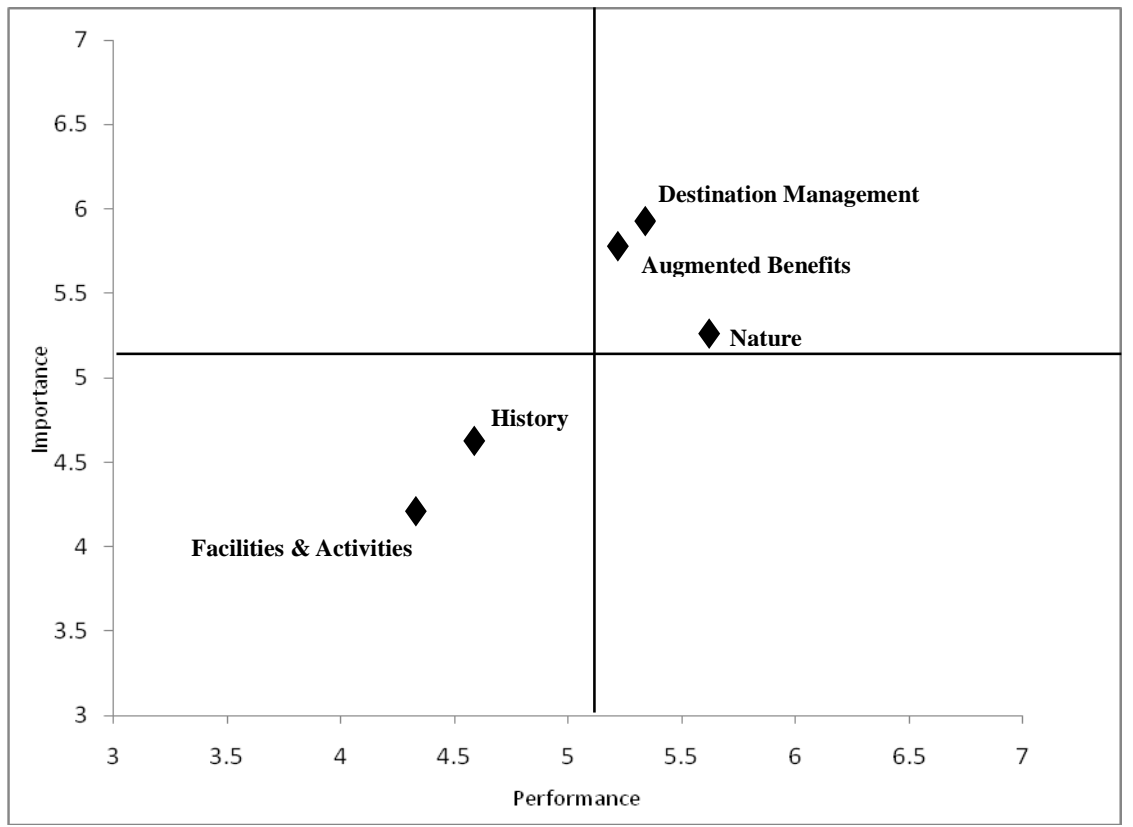


Table 7. Summary of Results - Paired-Samples $t$ tests.

\begin{tabular}{|c|c|c|c|c|c|c|c|c|}
\hline & \multicolumn{5}{|c|}{ Paired Differences } & \multirow[b]{3}{*}{$\mathrm{t}$} & \multirow[b]{3}{*}{ df } & \multirow{3}{*}{$\begin{array}{c}\text { Sig. } \\
\text { (2-tailed) }\end{array}$} \\
\hline & & & & \multicolumn{2}{|c|}{$\begin{array}{c}99 \% \text { Confid. Interval } \\
\text { of the Difference }\end{array}$} & & & \\
\hline & Mean & Std. Dev. & Std. Error Mean & Lower & Upper & & & \\
\hline Dest. Mgnt (Pub/Priv) & .31686 & .47853 & .02580 & .25003 & .38369 & 12.281 & 343 & .000 \\
\hline Facilities \& Activities & .40698 & .53859 & .02904 & .33176 & .48219 & 14.015 & 343 & .000 \\
\hline Nature & .08314 & .62275 & .03358 & -.00383 & .17011 & 2.476 & 343 & .014 \\
\hline Augmented Benefits & .39390 & .56243 & .03032 & .31535 & .47244 & 12.989 & 343 & .000 \\
\hline History & .09157 & .65769 & .03546 & -.00028 & .18342 & 2.582 & 343 & .010 \\
\hline
\end{tabular}

